\title{
時期特異的‧領域特異的な血管化が担う，神経幹細胞・前駆細胞の調節機構
}

\author{
水谷健一
}

\section{Spatiotemporally Dependent Vascularization Regulates Neural Stem and Progenitor Cells}

\author{
Ken-ichi Mizutani \\ Laboratory of Stem Cell Biology, Graduate School of Pharmaceutical Sciences, Kobe Gakuin \\ University; 1-1-3 Minatojima, Chuo-ku, Kobe 650-8586, Japan.
}

(Received August 27, 2020)

\begin{abstract}
Blood vessels including arteries, veins, and capillaries, are densely spread throughout the body. One round of systemic blood circulation through these blood vessels occurs approximately every minute, and blood sent by the heart transports oxygen, nutrients, and fluid to cells throughout the body. This nourishes cells, tissues, and organs and maintains homeostasis. The relatively simple structure of blood vessels consists of endothelial cells surrounded by a basal lamina and pericytes covering the outer layer. However, blood vessels patterning markedly varies among tissues. The diversity and plasticity of vascular networks are considered vital for this system to facilitate distinct functions for each tissue. Recent studies revealed that blood vessels create a tissue-specific niche, thus attracting attention as biologically active sites for tissue development. This vascular niche establishes specialized microenvironments through both direct physical contact and secreted-soluble factors. Here, we review advances in our understanding of how the vascular niche is utilized by neural stem and progenitor cells during neocortical development, and describe future perspectives regarding new treatment strategies for neural diseases utilizing this vascular niche.
\end{abstract}

Key words_— vascular niche; neocortex; angiogenesis; neural stem cell; neural differentiation; development

\section{1. 脳の発生と機能維持を可能にする微小環境}

私たち哺乳類の脳は，自己複製能と多分化能を併 せ持った未分化な細胞である神経幹細胞から生み出 され，ニューロン，アストロサイト，及びオリゴデ ンドロサイトの発生と分化が巧みに制御されながら 構築される. ${ }^{1)}$ 胎児脳に発生する神経幹細胞は, 脳 室带（ventricular zone; VZ）で分裂を続けること で細胞を生み出し，細胞周期を離れた未成熟な細胞 が，将来の大脳皮質を構成する皮質板（cortical plate; CP) へと放射方向の細胞移動を開始するが, 一部の細胞集団は脳室下帯（subventricular zone; SVZ）で再び細胞分裂をしてから最終分化へ向かう (Fig. 1)。一方，中間帯 (intermediate zone; IZ) で形態を多極性細胞へと一度変化させた後に移動を 続けて，やがてサブプレート（subplate; SP）近傍

神戸学院大学大学院薬学研究科幹細胞生物学研究室 （干650-8586 神戸市中央区港島 1-1-3）

e-mail: mizutani@pharm.kobegakuin.ac.jp

本総説は, 日本薬学会第 140 年会シンポジウム S10 で

発表した内容を中心に記述したものである.
で双極性細胞へと変化することで，分化細胞に成熟 する集団も観察され，極めて複雑な分化様式で組織

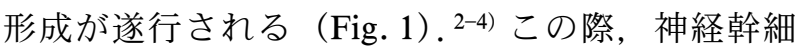
胞は，発生初期ではニューロンのみに分化するもの の, 発生後期になるとその能力を失い, グリア細胞 だけに分化するように変化するが，こうした幹細胞 の能力5,6) がごのように制御されているかも依然と して謎が多い。実際，神経前駆細胞，グリア前駆細 胞など，制限された能力を持つ幹細胞（前駆細胞） が存在し，各々の細胞系譜が複雑に絡み合いなが ら, 細胞構築が可能になると考えられている. こう した多様な幹細胞・前駆細胞の分化制御が何によっ て統合され, 結果として, 整然と機能する脳の形成 がどのように可能になるのかについてはいまだに不 明である. 加えて, 脳の形成が完了した後も生涯に わたってニューロンが新生されることが知られてい るが，これには側脳室周囲の SVZ と海馬の歯状回 顆粒細胞下帯の少なくとも 2 力所に局在する成体神 経幹細胞がその役割を担う.7) 成体神経幹細胞は, 他の組織に存在する恒常性を維持する組織幹細胞と 


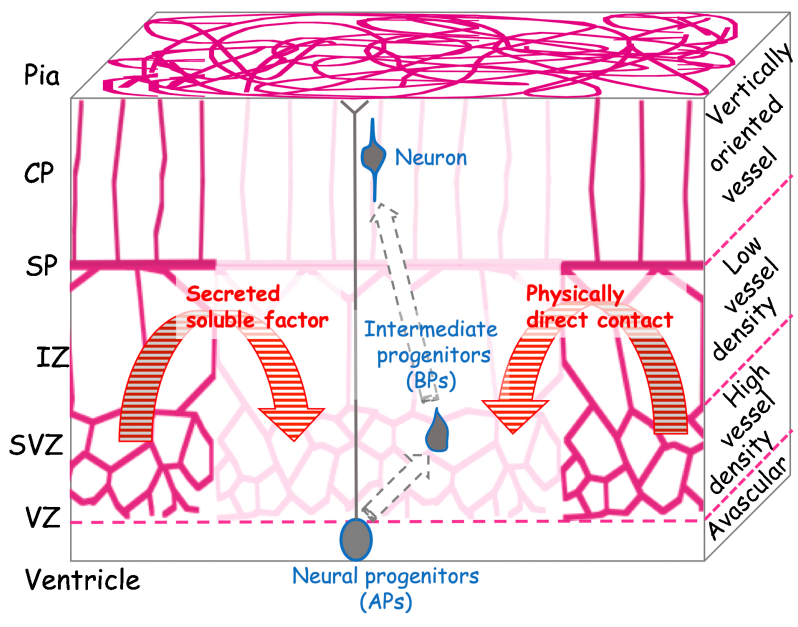

Fig. 1. Regularity of Angiogenesis during Neocortical Development

The vascular niche constitutes specialized microenvironments through both direct physical contact and secreted-soluble factors to regulate neurogenesis during neocortical development. Newborn neurons near the ventricle undergo multiphasic radial migration to reach their final position within the cortical plate (CP) after passing the subplate (SP). During this process, postmitotic immature neurons originating from neural progenitors (apical progenitors; APs) remain in the ventricular zone (VZ), or move from the VZ toward the subventricular zone (SVZ) and intermediate zone (IZ), where intermediate progenitors (basal progenitors; BPs) have localized. (Color figure can be accessed in the online version.)

同様に，細胞分裂能力を維持しながらも稀にしか分 裂せず，ニューロンとグリア細胞を生み出す幹細胞 が，一生涯に渡って維持できると考えられている.

こうした成体神経幹細胞は, 胎生期の神経幹細胞の 一部で，分裂頻度を低く保つことができる特殊な神 経幹細胞に由来することが示唆されているが, ${ }^{8)} こ$ れらの幹細胞が，どのように組織を構成する細胞の 数や機能を維持できるのかについては，依然として 未解明の問題が数多く残されている.

こうした幹細胞の維持・分化制御機構は, 細胞内 在性因子と細胞外因子がともに重要な役割を果たす ことが報告されてきた. ${ }^{7,9)}$ 中でも, 幹細胞の細胞外 因子としての微小環境（Niche，ニッチ）は，50 年 以上前に提唱された概念であり, ${ }^{10,11)}$ 生体内で幹細 胞がその性質を調節・維持するために必要な環境 が，組織の発生・維持に重要であることが指摘され ている.この幹細胞ニッチには，微小環境を構築す る細胞が供給する接着分子, サイトカイン, ケモカ イン，細胞外基質や，幹細胞に作用するニッチ分子 としての酸素分子などが含まれるが，筆者らの研究 室では，特に，血管由来の微小環境，血管ニッチが 果たす役割に着目して研究を発展させている（Fig. 1). ${ }^{12-14)}$
血管は，組織細部にわたり養分や酸素を運搬する 極めて重要な器官の 1 つであるが，大脳皮質におけ る血管発生は，中胚葉由来の内皮細胞と神経堤由来 の周皮細胞が終脳基底核近傍から進入し，腹側から 背側へとダイナミックに移動しながら血管網を構築 するが，適切に血管網をつくることが組織構築に必 要不可欠なため, 極めて精巧に血管発生が進行する ことが明らかになっている (Fig. 1).12-14) この際, 血管を構成する血管内皮細胞や周皮細胞は，神経系 の細胞と複雑な相互作用を伴いながら発生が同期 的・同調的に進行することで，極めて多様性に富ん だ細胞からなる脳が形成され，また，成体脳が多彩 な機能を発現・維持するためにも，これらのクロス トークが重要となる。本稿では，神経幹細胞の性質 を支持する生物学的適所としての血管ニッチの役割 に着目し，発生期の大脳皮質を中心に議論する.

\section{2. 血管系細胞との物理的な接触に由来する微小} 環境の役割

胎生期や成体神経幹細胞の増殖や分化に影響を及 ぼす，血管由来の微小環境の実体は，血管系細胞と の物理的な接触や，血管系細胞より分泌される液性 因子が中心的な役割を果たすと考えられている.

筆者らは，血管内皮細胞増殖因子 (vascular endothelial growth factor; VEGF) 受容体のリポーター マウス (VEGFR1-tdsRed 及び VEGFR2-EGFP BAC トランスジェニックマウス）を用いて, ${ }^{15,16)}$ 発生期 大脳皮質を詳細に観察した結果，大脳皮質の実質に 形成される脳室周囲血管は，その単位面積当たりの 密度や分岐点を極めて規則的に調節しながら発生を 進めることを見い出した. ${ }^{12)}$ 例えば，胎生 14 日以 降に構築される大脳皮質における血管網の形態学的 な特徵は，規則性が極めて高く，その構造は脳室面 に形成される無血管領域，SVZ/IZ に形成される蜂 の巣状の毛細血管，及びCP に形成される直線状の 毛細血管で構成されていることが分かった（Fig. 1)。特に，SVZ や IZ 近傍では最も血管密度が高い 領域が形成されているが，ここに位置する蜂の巣状 血管は，非脳室面で分裂する中間型前駆細胞 (basal progenitors; BPs，主に SVZ や IZ に局在す る phospho histone H3 陽性細胞）（Fig. 1） と約 $80 \%$ 程度の高頻度で物理的に接触する一方で，主に IZ に局在するオリゴデンドロサイト前駆細胞 (oligodendrocyte precursor cells; OPCs，主に IZ で 
a
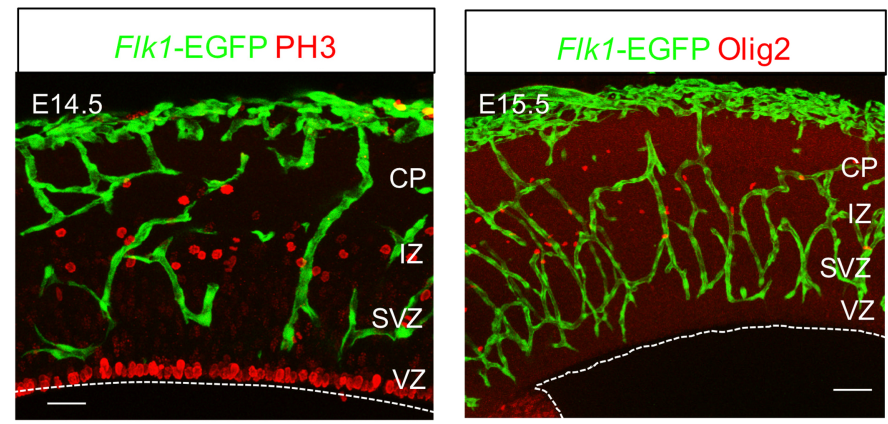

b
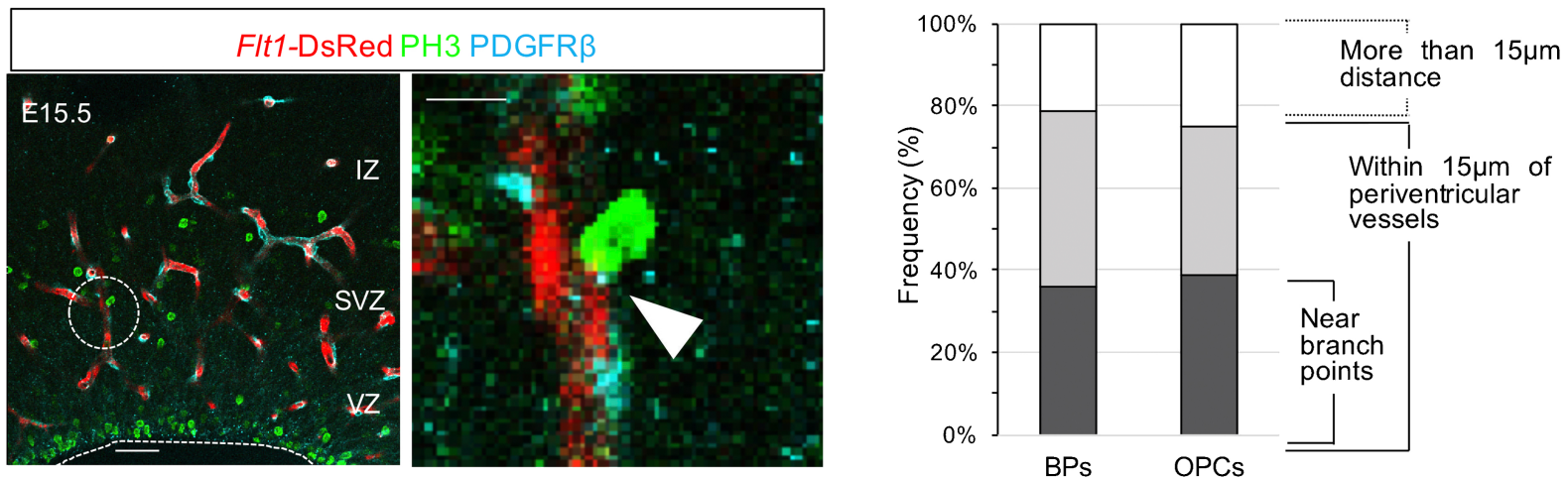

Fig. 2. Spatiotemporally Restricted Vascularization Provides a Perivascular Niche for Basal Progenitors and Oligodendrocyte Precursor Cells

(a) Immunofluorescence of PH3 and Olig2 in embryonic (E) 14.5 (left) or E15.5 (right) Flk1-EGFP neocortex. Scale bars: $50 \mu \mathrm{m}$. (b) PH3 ${ }^{+}$cells (green) contacting the vasculature at sites with weak pericyte (PDGFR $\beta$; blue) coverage in E15.5 Flt 1-tdsRed neocortex. Quantification of $\mathrm{PH}_{3}{ }^{+}$or Olig2 ${ }^{+}$cells $($right panel), which are located near a branch point, by analysis of Z-stack images of a $200 \mu \mathrm{m}$ vibratome section from E15.5 Flt 1 -tdsRed mice. Scale bars: $50 \mu \mathrm{m}$ (left panel) and $10 \mu \mathrm{m}$ (right panel). (Color figure can be accessed in the online version.)

観察される Olig2 と NG2 二重陽性細胞）も約 $80 \%$ 程度の高頻度で毛細血管と物理的に接触することが 観察された（Fig. 2)。BPs は血管の分岐点に優先 的に局在するとの報告 ${ }^{17)}$ があるが，筆者らの観察で は, BPs も OPCs もおおよそ $80 \%$ が血管から $15 \mu \mathrm{m}$ 以内 (細胞の核の中心から最も近い血管までの距離) の血管周囲に局在し，このうちのおおよそ半数 （BPs 及び OPCs の全体の $40 \%$ 程度）が血管分岐点 の近傍に位置することが見い出された [Fig. 2 (b) ].さらには，コンフォーカルのZ-stack 画像を 一面一面確認して詳細に観察を行った結果，BPs は 周皮細胞と優先的に接触する一方で, OPCs は周皮 細胞の巻き付きが疎で内皮細胞が露わになつている 所へ優先的に接触するといつた特異性が見い出され た. ${ }^{12 ）}$ 興味深いことに, BPs と周皮細胞，OPCs と 内皮細胞の物理的な接触は，いずれにおいても分化 レベルが制御されていることが共培養系で確認され たことから，大脳皮質を構成する分化細胞へと運命 付けられる手前の段階で（SP を越える手前の SVZ や IZで), BPs や OPCs が最終分化するタイミン
グを調節する際に，血管系細胞との物理的な接触を 利用している可能性が推察された。そこで，脳室面 で分裂する神経幹細胞 (apical progenitors; APs) を子宮内エレクトロポレーション法によって蛍光夕 ンパク質で標識し，脳室面で分裂した後に非脳室面 で再び BPs として分裂する細胞集団を追跡し，毛 細血管とどのような関連性を持って最終分化に向か うかについてスライス培養を用いたタイムラプス解 析を行った. ${ }^{12)}$ その結果，BPs の中でも一定の割合 の細胞集団は，毛細血管と接触（内皮が露呈してい る場所）した状態を 12 時間程度継続した後，やが て血管から離れ，その後に細胞移動を再開すること が明らかとなつた。 また，OPCsについても，血管 を足場にして細胞移動した後に，血管と離れること で分化に向かうことが示されている18)ことから，血 管との物理的な接触は分化レベルの調節に寄与して いる可能性が示唆された。最近の研究で, 低酸素誘 導因子 (hypoxia-inducible factor $1 \alpha$; HIF- $1 \alpha$ ) の安 定化は，Wnt7a/7b の活性化を介して OPCs の分化 を制御することが報告されているが, ${ }^{19)}$ 筆者らの観 
察では, OPCs と内皮細胞が物理的に接触する IZ 近傍では，胎生 15 日目頃になると，この領域にお ける HIF-1 $\alpha$ の発現が一過的に誘導され，その後胎 生 16 日以降になると, 上述の通り血管から離れて $\mathrm{SP}$ を越えて, 成熟した細胞として CP へと侵入し ていくことが確認されている.12)さらには， VEGFR1 のヘテロノックマウスの解析から，血管 密度が変化すると，これらの幹細胞・前駆細胞が減

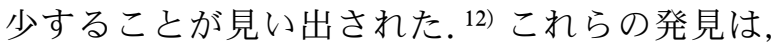
BPs や OPCs などの神経系の幹細胞・前駆細胞が 物理的な接触を介して，血管近傍二ッチが，神経分 化を制御する重要な生理機能を担う可能性が示唆さ れた。

さらに筆者らは, 脳室面に近い領域は, VEGFR1 陽性の毛細血管が観察されない無血管領 域であることに注目して詳細に解析をした結果，こ こでは，むしろ VEGFR2 陽性の血管先端細胞が形 成され，これが脳室面に向かって維持されるが，非 脳室面側に向かってはほとんど形成されないという 固有の微小環境を構築していることを見い出し た. ${ }^{12)} こ の$ 特殊な毛細血管は，胎生 12 日から 14 日 頃までの限られた時期に過剩に形成され，やがて消 失するが，電子顕微鏡観察やトランスウェルを用い た共培養系の解析から，この一過的に形成される血 管先端細胞が，脳室面で分裂する APs と $\beta 8$-インテ グリンを介して物理的に接触し，これによって幹細 胞の未分化マーカー遺伝子の発現が充進する（幹細 胞としての性質が高まる）ことを明らかにしてい る. ${ }^{12)}$

筆者らは，これら一連の結果から，脳組織内の毛 細血管の構造が領域毎に大きく異なり，異なる血管 ニッチを時空間依存的に規則的に構築することで, 各々の神経系の幹細胞・前駆細胞の増殖や分化を巧 みに調節し，こうした微小環境の制御が多種多様な 細胞から構成される大脳皮質の発生を可能にしてい ると結論付けた. ${ }^{12)}$

\section{3. 血管系細胞からの供給因子に由来する微小環} 境の役割

血管由来の微小環境が制御する大脳皮質の形成・ 維持機構は，上述のような細胞間の接触を介した調 節のみならず，血管から供給される様々な液性因子 が重要な役割を果たす可能性が指摘されている.

大脳皮質の実質を形成する脳室周囲血管と神経堤
由来の周皮細胞は，各々，終脳基底核近傍から進入 し, 胎生 10 日頃に腹側を出発点として背側へと移 動しながら血管網を拡大していくが，この際，内皮 細胞は腹側から背側の大脳皮質へと進入する際に, Dlx2 から Pax6 へとその発現遺伝子を変化させ, ${ }^{20)}$ こうした内皮細胞の不均一性が大脳皮質の発生を調 節する上で重要な生理機能を担うことが報告されて いるが，脳室周囲血管と軟膜血管は $\gamma$-アミノ酪酸 （ $\gamma$-aminobutyric acid; GABA）の産生量が異なり, この違いが，抑制性神経細胞が脳室に近い移動ルー 卜を選択するか軟膜に近い移動ルートを選択するか の調節に寄与することが報告されている. ${ }^{21)}$ また， 神経幹細胞が血管由来の液性因子によって増殖・維 持に関与していることは古くから指摘されていた が, ${ }^{22)}$ 最近の研究で，成体の SVZ に局在する血管 内皮細胞が神経幹細胞に静止期ニッチ情報（静止期 に保つための固有の微小環境）を伝達することで未 分化性を維持し，これには分泌型アミロイド前駆体 (soluble amyloid precursor protein; sAPP）が関与す ることが報告されている. ${ }^{23)}$

前述の通り，筆者らは，発生期の大脳皮質では限 られた時期に脳室面に $20 \mu \mathrm{m}$ 前後の無血管領域が 形成され，ここに特殊な内皮細胞が動員されること を報告しているが，未分化な APs が盛んに分裂す る胎生 12.5 日から 13.5 日頃は，この領域では HIF-1 $\alpha$ の発現が極めて高く，これと一致して VEGF の発現も一過的に充進していることを確認 している. ${ }^{12)}$ VEGF は，血管内皮細胞の増殖や遊走 を促す増殖因子である一方で，血管透過性の充進因 子としても知られる，そこで，筆者らは，分子量が 数百からなる蛍光色素を灌流し，毛細血管から漏出 する色素の領域特異性を評価したところ，蛍光色素 の局在は無血管領域（VEGF の発現の領域特異性） と概ね一致し，VZや SVZ で有意に高いが，IZよ りも軟膜側の領域ではほとんど検出されないことを 確認しており，この現象は特に胎生 12.5 日から 13.5 日頃で顕著であることが見い出された $[\mathrm{Fig} .3$ (a)．そこで，この時期の周皮細胞の局在を確認し たところ，巻き付きが密な領域もあれば，疎な領域 も確認されるが，その特異性は見い出せなかつ た. ${ }^{12)}$ 一方，神経幹細胞特異的に HIF- $1 \alpha$ をノック アウトしたマウスを用いて，同様の灌流実験を行っ たところ，ノックアウトマウスでは蛍光色素の漏出 
a
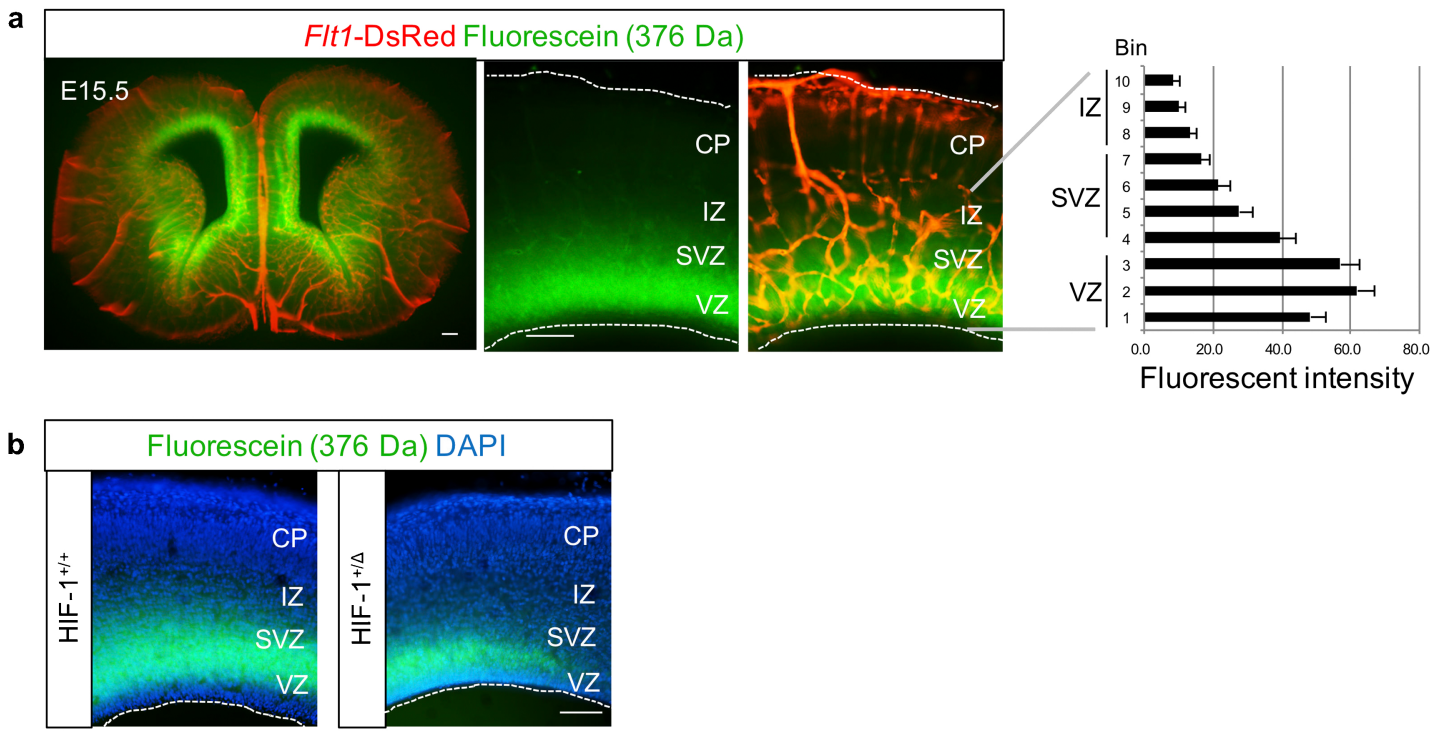

Fig. 3. Vascular-derived Small Molecules Preferentially Access the Ventricular Zone

(a) Sodium fluorescein, a small molecular weight molecule (376 Da), was perfused into the blood of an E15.5 Flt1-tdsRed mouse, and we examined whether sodium fluorescein was detected in the neocortex. The Fluorescent intensity of sodium fluorescein was quantified using ImageJ software. Background signals in the cortical plate (CP) were subtracted from the fluorescent intensity of each binning region. (b) The perfusion of sodium fluorescein in HIF-1 $\alpha$ conditional knockout mice was performed, and the distribution of fluorescence was compared with that of WT. Scale bars: $50 \mu \mathrm{m}$. (Color figure can be accessed in the online version.)

が減少し [Fig. 3(b)]，また，このマウスでは脳室 面近傍の血管先端細胞が減少することが確認されて いることから，VZ 近傍の低酸素ニッチが特殊な毛 細血管を誘導し，これが血管由来の液性因子の供給 に関与する可能性が示唆された。これら一連の結果 から，未分化な神経幹細胞が維持される領域では, 無血管に伴う低酸素環境が構築され，血管透過性が 高い特殊な血管ニッチが能動的に形成され，血管か ら供給されるなんらかの小分子が大脳皮質の発生を 調節している可能性が示唆される。現在，筆者らの 研究室では，これらの現象をさらに追求している.

\section{4. 血管ニッチの制御が可能にする神経疾患の理} 解

血管由来の微小環境は，胎生期の脳形成ばかりで なく, 脳の機能維持にも重要な役割を果たすと考え られており，加齢に伴う血管ニッチの破綻は，様々 な神経疾患の発症・進展との関連性が明らかとなっ ている．また，血管ニッチの生理機能の理解は，新 たな治療戦略に応用できる可能性が最近の研究で注 目されている.

例えば，脳梗塞モデル動物に，低分子の蛍光物質 を封入した造血幹細胞を投与すると，脳梗塞巣の障 害を受けた血管に蛍光物質が分布することが確認さ れており，これにはギャップ結合を介して，造血幹 細胞と血管内皮細胞が物理的に接触することが関与
することが報告されている. ${ }^{24)}$ この際，接触した血 管内皮細胞へグルコースが供給され，これが引き金 となって血管内皮細胞における HIF-1 $\alpha$ の活性化が 生じ，これが脳梗塞巣近傍における血管再生に寄与 することが明らかにされている。 また，脳梗塞など の障害脳によって，SVZで生み出された新生 ニューロンが障害領域へ移動し，これが神経再生や 機能回復に貢献する可能性が期待されているが，新 生ニューロンが障害部位へと移動するための足場と して血管が重要な役割を果たすことが報告されてい る。この際，血管内皮細胞から供給される脳由来神 経栄養因子（brain-derived neurotrophic factor; BDNF $)^{25)}$ ，血管内皮細胞が発現するラミニンと 新生ニューロンが発現する $\beta 1$-インテグリンの相互 作用 ${ }^{26)}$ が，障害部を移動するニューロンの血管に 沿つた細胞移動を制御することが明らかにされてい る.

一方，毛細血管は上述のような様々な栄養・液性 因子の供給源となるばかりでなく，不要なものを回 収し，これを脳外へと排出することが恒常性の維持 に重要であることが最近の研究で明らかになりつつ ある。つまり，正常な血管環境を有する脳では，ア ミロイド $\beta$ が生成しても，血管に沿つた血管周囲 腔から脳脊髄液中へと排出され，老廃物として血液 中に移され最終的に末梢へとクリアランスされるこ 
とが明らかになっており, 27)このためには血管ニッ チの維持が必要とされる。 また, 脳の恒常性維持の ためには，血管のバリア機能としての血管ニッチ, 血液脳関門が維持されることも重要であり，アルツ ハイマー病や認知症など様々な神経疾患が，血管の バリア機能の破綻と密接な関連性があることが報告 されている. ${ }^{28,29)}$ しかしながら, 最近の研究では, 脳における毛細血管は，動脈や静脈と比べて分子的 な劣化を受け易いことが指摘されていることか ら, ${ }^{30)}$ 今後, 血管由来のニッチを制御できる分子機 構の詳細が明確化されることが期待される.

5. おわりに

大脳皮質に形成される血管近傍ニッチと低酸素 ニッチは神経系細胞と密接な相互作用を繰り返しな がら，精確に発生を遂行する。つまり，脳血管は， 単に成長する神経系からの酸素や栄養の要求に応答 するために受動的に発生するのではなく，不均質性 を持った内皮細胞（個々の時間特性・領域特性）と 不均質性を持った神経系細胞が綿密に連携すること で，大脳皮質の血管系・神経系の細胞構築が可能と なる，一方，加齢に伴う血管ニッチの破綻は，血管 の質と量の劣化に至り，内皮細胞や周皮細胞の機能 異常から局所的な虚血・炎症・排出機能低下を介し てアルツハイマー病などの病態の発症・進展に関与 する，今後, 脈管系の発生・発達・老化機構を解く ことで, 幹細胞・前駆細胞の分化制御機構をさらに 明確化するとともに，新たな治療戦略の概念を創出 していきたい.

謝辞本稿で記述した研究は, 当研究室で推進 してきた脳血管の発生制御機構を明らかにする研究 プロジェクトに関与するところが大きく, 当研究室 の室員であった鈴木真理子研究員，山西恵美子研究 員, 渡部千里院生などご協力頂いた研究室メンバー の皆様と，ライブイメージング解析にご協力頂いた 愛知県医療療育センターの永田浩一部長と田端秀典 室長，及び血管レポーターマウスの提供や数多くの 助言を頂いた滋賀医科大学の依馬正次教授に深く御 礼申し上げます。

利益相反＼cjkstart開示すべき利益相反はない.

\section{REFERENCES}

1) Temple S., Nature, 414, 112-117 (2001).

2) Tabata H., Nakajima K., J. Neurosci., 23, 9996-10001 (2003).

3) Inoue M., Iwai R., Tabata H., Konno D., Suzuki-Komabayashi M., Watanabe C., Iwanari H., Mochizuki Y., Hamakubo T., Matsuzaki F., Nagata K., Mizutani K., Development, 144, 385-399 (2017).

4) Iwai R., Tabata H., Inoue M., Nomura K., Okamoto T., Ichihashi M., Nagata K., Mizutani K., Biochem. Biophys. Res. Commun., 495, 388-394 (2018).

5) Mizutani K., Saito T., Development, 132, 1295-1304 (2005).

6) Mizutani K., Yoon K., Dang L., Tokunaga A., Gaiano N., Nature, 449, 351-355 (2007) .

7) Bond A. M., Ming G. L., Song H., Cell Stem Cell, 17, 385-395 (2015).

8) Furutachi S., Miya H., Watanabe T., Kawai H., Yamasaki N., Harada Y., Imayoshi I., Nelson M., Nakayama K. I., Hirabayashi Y., Gotoh Y., Nat. Neurosci., 18, 657-665 (2015).

9) Urbán N., Guillemot F., Front. Cell. Neurosci., 8, 396 (2014).

10) Curry J. L., Trentin J. J., Dev. Biol., 15, 395413 (1967).

11) Schofield R., Blood Cells, 4, 7-25 (1978).

12) Suzuki-Komabayashi M., Yamanishi E., Watanabe C., Okamura M., Tabata H., Iwai R., Ajioka I., Matsushita J., Kidoya H., Takakura N., Okamoto T., Kinoshita K., Ichihashi M., Nagata K., Ema M., Mizutani K., Cell Rep., 29, 1113-1129 (2019) .

13) Takashima S., Watanabe C., Ema M., Mizutani K., Neurochem. Int., 129, 104481 (2019) .

14) Mizutani K., Yakugaku Zasshi, 140, 521-527 (2020) .

15) Matsumoto K., Azami T., Otsu A., Takase H., Ishitobi H., Tanaka J., Miwa Y., Takahashi S., Ema M., Genesis, 50, 561-571 (2012).

16) Ishitobi H., Matsumoto K., Azami T., Itoh F., Itoh S., Takahashi S., Ema M., Exp. Anim., 59, 615-622 (2010). 
17) Javaherian A., Kriegstein A., Cereb. Cortex, 19 (Suppl. 1), i70-i77 (2009).

18) Tsai H. H., Niu J., Munji R., Davalos D., Chang J., Zhang H., Tien A. C., Kuo C. J., Chan J. R., Daneman R., Fancy S. P., Science, 351, 379-384 (2016).

19) Yuen T. J., Silbereis J. C., Griveau A., Chang S. M., Daneman R., Fancy S. P. J., Zahed H., Maltepe E., Rowitch D. H., Cell, 158, 383-396 (2014).

20) Vasudevan A., Long J. E., Crandall J. E., Rubenstein J. L., Bhide P. G., Nat. Neurosci., 11, 429-439 (2008).

21) Won C., Lin Z., Kumar T. P., Li S., Ding L., Elkhal A., Szabó G., Vasudevan A., Nat. Commun., 4, 2149 (2013).

22) Shen Q., Goderie S. K., Jin L., Karanth N., Sun Y., Abramova N., Vincent P., Pumiglia K., Temple S., Science, 304, 1338-1340 (2004).

23) Sato Y., Uchida Y., Hu J., Young-Pearse T. L., Niikura T., Mukouyama Y. S., Development, 144, 2730-2736 (2017).

24) Kikuchi-Taura A., Okinaka Y., Takeuchi Y., Ogawa Y., Maeda M., Kataoka Y., Yasui T., Kimura T., Gul S., Claussen C., Boltze J., Taguchi A., Stroke, 51, 1279-1289 (2020).

25) Snapyan M., Lemasson M., Brill M. S., Blais M., Massouh M., Ninkovic J., Gravel C., Ber- thod F., Götz M., Barker P. A., Parent A., Saghatelyan A., J. Neurosci., 29, 4172-4188 (2009).

26) Fujioka T., Kaneko N., Ajioka I., Nakaguchi K., Omata T., Ohba H., Fässler R., GarcíaVerdugo J. M., Sekiguchi K., Matsukawa N., Sawamoto K., EBioMedicine, 16, 195-203 (2017).

27) Storck S. E., Meister S., Nahrath J., Meißner J. N., Schubert N., Di Spiezio A., Baches S., Vandenbroucke R. E., Bouter Y., Prikulis I., Korth C., Weggen S., Heimann A., Schwaninger M., Bayer T. A., Pietrzik C. U., J. Clin. Invest., 126, 123-136 (2016).

28) Sweeney M. D., Sagare A. P., Zlokovic B V., Nat. Rev. Neurol., 14, 133-150 (2018).

29) Nation D. A., Sweeney M. D., Montagne A., Sagare A. P., D’Orazio L. M., Pachicano M., Sepehrband F., Nelson A. R., Buennagel D. P., Harrington M. G., Benzinger T. L. S., Fagan A. M., Ringman J. M., Schneider L. S., Morris J. C., Chui H. C., Law M., Toga A. W., Zlokovic B. V., Nat. Med, 25, 270-276 (2019).

30) Chen M. B., Yang A. C., Yousef H., Lee D., Chen W., Schaum N., Lehallier B., Quake S. R., Wyss-Coray T., Cell Rep., 30, 4418-4432 (2020). 